\title{
Cahiers de recherche du centre Jacques Berque,
} $n^{\circ} 2$

\section{(2) OpenEdition}

\section{Journals}

Édition électronique

URL : http://journals.openedition.org/transcontinentales/1427

DOI : 10.4000/transcontinentales. 1427

ISBN : 978-2-8218-1410-3

ISSN : $1775-397 X$

Éditeur

Editions de la maison des sciences de l'homme

\section{Édition imprimée}

Date de publication : 31 décembre 2005

Pagination : 155

ISBN : 2200-92168-3

ISSN : $1950-1684$

\section{Référence électronique}

"Cahiers de recherche du centre Jacques Berque, $n^{\circ} 2$ », Transcontinentales [En ligne], 1 | 2005, document 17, mis en ligne le , consulté le 25 septembre 2020. URL : http://journals.openedition.org/ transcontinentales/1427; DOI : https://doi.org/10.4000/transcontinentales.1427

Ce document a été généré automatiquement le 25 septembre 2020

Tous droits réservés 


\section{Cahiers de recherche du centre Jacques Berque, $n^{\circ} 2$}

\section{RÉFÉRENCE}

Rabat, Centre Jacques Berque, 2005

1 Un riche numéro construit à partir des séminaires «Islams et islamités » organisés par le centre Jacques Berque en 2002 et 2003 à Rabat. Les comptes rendus d'une vingtaine de contributions se structurent autour de cinq thèmes: islams et islamités; méconnaissances et savoirs; islam et sociétés; islam et figures de l'individu; islam, société et politique; droit et perspectives de laïcisation. La question de la sécularisation, celle de la femme et du féminisme, les islamismes et les crises contemporaines de l'islam, les effets de la normalisation de l'islam politique sont abordés. L'ensemble du recueil, aux nombreuses contributions marocaines témoigne du fertile dialogue entre histoire, droit, sciences sociales, et thématiques plus politiques. 